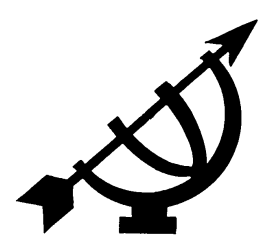

\title{
The responsibility of the state and the calling of the church in the South African context of crime and violence - a theological investigation
}

\author{
J.H. van Wyk
}

Researcher: School of Ecclesiastical Sciences

Potchefstroom Campus

North-West University

POTCHEFSTROOM

E-mail: amievw@intekom.co.za

\begin{abstract}
The responsibility of the state and the calling of the church in the South African context of crime and violence a theological investigation
\end{abstract}

This article investigates not only the complex relation between church and state, but also the general and particular responsibilities of the state towards crime and violence. In this regard attention is also paid to the calling and task of the church. The conclusion arrived at is rather alarming in that the moral situation in South Africa has reached a nadir such that the state and the church - each in its own way - has to broach the challenge with great urgency. On the one hand crime and violence should be brought back to "normal" proportions, while on the other hand, South Africa is in desperate need of a new moral orientation and a new culture of respect for human life and the possessions of others.

\section{Opsomming}

Die verantwoordelikheid van die staat en die roeping van die kerk in die Suid-Afrikaanse konteks van misdaad en geweld - 'n teologiese ondersoek

Hierdie artikel ondersoek nie net die ingewikkelde verhouding tussen kerk en staat nie, maar ook die algemene en besondere verantwoordelikhede van die staat ten opsigte van misdaad en geweld. Aandag word ook gegee aan die roeping en taak van die kerk in hierdie verband. Die verontrustende gevolgtrekking 
word gemaak dat die morele situasie in Suid-Afrika 'n ontstellende punt bereik het en dat die staat en kerk - elk op sy eie wyse - die uitdaging met groot dringendheid moet aanpak. Aan die een kant moet misdaad en geweld teruggebring word tot "normale" vlakke, terwyl Suid-Afrika aan die ander kant 'n dringende behoefte het aan 'n nuwe morele oriëntasie en kultuur van respek vir menslike lewe en die besittings van ander.

\section{Introduction}

To discuss "the topic of crime and violence in contemporary South Africa" is a very challenging undertaking. It may even be asked why the focus on this topic after ten years of euphoria and democracy? Is there something (morally) wrong with our society?

At the outset then a few preliminary and explanatory remarks:

\subsection{The nature of state and church}

The issue about the responsibility of the government and the calling of the church in a context of crime and violence is closely related to, and interdependent on the issue about the nature of state and church. The state is a political institution, whereas the church is a spiritual community. 1 The calling of the church cannot be understood without a distinct understanding of what the church is and of what the church confesses about God, man, the world and the meaning of life.

\subsection{The relation between state and church}

Another aspect refers to the way in which we view the relation between state and church, of which I will mention only three (see Van Wyk, 1991:213-244):

- The first option to view the relation between state and church is that of isolation: the church withdraws herself from public life to the sphere of inner life, meditation, devotion and liturgy (Smit, 1996:194). This option, however, contradicts the command of Christ that his followers should be the salt of the earth and the light of the world (Matt. 5: 13-16).

(1970; 1972), Küng (1967), Moltmann (1975) and Van't Spijker et al. (1990). 
- The second option is the view of identification (and conformation) in which church and state become so intertwined that there is no clear distinction between them. The church then becomes the state in prayer and the state becomes the church in action. The church becomes an instrument in the hands of the state to promote state affairs (Smit, 1996:198). Church life becomes the religious aspect of state life. However, this option clearly contravenes the clear teaching of the New Testament on the church as a unique community in society.

The above view entails that a theocratic ideal is not plausible in a plural society - although Christians always believe and confess that God controls the universe and the course of history.

- A third option is sometimes described as critical solidarity (VillaVicencio, 1995:58), although I prefer the formulation critical association (or co-operation). According to this approach a clear distinction is made between church and state, each with its own calling, task and competence, although both are also related in many ways - as we shall see. This model implies that times will occur when the church will appreciate (and associate with) the state's achievements, and times will occur when the church will criticise what the state does. There will be times of cohesion and times of confrontation, times of consonance and times of contradiction.

In this approach I would like to follow this last model, because it is deeply founded on the teaching of the Old and New Testaments as well as on many confessions and on the church order of (Reformed) churches.

\subsection{The new challenge is the same as the previous one}

Although it can be argued that the South African context has fundamentally changed since 1994, and concomitantly the relation between the (neutral) state and the church, and that the church is thus challenged to relate to the state in new ways, but basically the new challenge has the same requirements as the old one: no isolation from the state, no identification with the state (like the situation between 1948-1994), but critical association with the state. (In this respect the emphasis should be on association as well as on the element of being critical. These points of departure should be implemented in new and inventive ways - which I hope to clarify later. 


\subsection{The concept "church" includes many denominations}

Speaking of "the church in South Africa" is of course an oversimplification, because there are Afrikaans- and Englishspeaking, "black" and "white", and multicultural churches, Protestant, Catholic, Greek Orthodox and Charismatic churches. When I refer to "the church" we have to keep in mind that there are many "denominations" with their own histories, traditions and approaches.

As far as the traditional Afrikaans churches are concerned: they experience what I would call a "legitimacy crisis", because they were silent during the years of apartheid, more or less justified it, and the question arises on what moral grounds can they now criticise the (democratic) government? To a certain extent this critical question concerns all churches that did not question apartheid strongly enough. If we turn back a hundred years: What about the silence of the English churches during and after the South African War (18991902) when one tenth of the Afrikaners in the Orange Free State and Transvaal were killed, and also many black people? ${ }^{2}$ (Giliomee, 2003:264).

From a Christian ethical perspective we may argue that two wrongs do not make a right, and that the Afrikaans churches also have an obligation to deliver a prophetic witness in society today, when necessary, although they should do it with humility and with an attitude in which they acknowledge their guilt and sin, their negligence and lack of courage in the past (see De Villiers, 1996:140-153).

The urgent question at this stage is: Will (predominant) black churches (and leaders) be willing to criticise the (predominant) black government when the government acts wrongly and will the government listen? Let us all take the lessons of the past as road signs to the future.

\subsection{Crime and violence can not be accepted or ignored}

I assume that the mere fact that a church conference 3 was convened in 2005 to discuss the topic of crime, is a clear indication

2 Pretorius (1985:57) calculates the numbers of white men, women and children killed in concentration camps as 27927 and the number of blacks killed in camps as 14154 (Pretorius, 1985:81).

3 I refer to the Conventicle of Reformational Churches in Southern Africa held in Pretoria on 3 March 2005. 
that such high levels of crime and violence exist in the country that society can no longer accept or ignore the phenomenon of crime. We should at all costs try to avoid a situation where we accept the abnormal to be normal. Something very urgent has to be done and something must be done.

The aim of this article is not to discuss and evaluate the various causes of crime and violence 4 - whether, and how it is related to poverty, unemployment, retaliation, drugs, crime syndicates, criminal orientation, a culture of "crime does pay", lack of relevant education and a lack of social moral orientation. We, however, have to bear these aspects in mind when we deal with the question what state and church should do in this regard.

We should also keep in mind the different manifestations of crime and violence, such as murder, theft, robbery, rape, child-abuse, hijacking, kidnapping, burglary, not to forget the many different forms of psychological, economical and structural forms of violence (see Van Wyk, 1991:87-108).

\subsection{The concepts of "state" and "government" are used interchangeably}

I want to make it clear that I use the concepts "state"5 and "government" interchangeably; I hope the context will clarify the meaning in each case. Although it is not precisely correct, it is common language to refer to the government as "the state".

In the next part or the article the responsibility of the state as far as the issue of crime and violence is concerned will be investigated.

\section{The responsibility of the state}

In this regard I want to examine two questions: First, what is the responsibility of the state in general and, second, what is the

4 Prof. Lawrence Schlemmer dealt with this matter in his address to the conference. He referred to the following causes: (1) Disintegrated social structures (due to urbanisation, migration, drugs, etc.; (2) alienation between the different classes in society (causing privatism, xenophobia, etc.); (3) an inefficient police force; (4) the activities of syndicates. See also Nel (2002:2141).

5 Strictly speaking, a "state" consists of (three levels of) "government" as well as of "citizens". 
responsibility of the state with regard to crime and violence in particular?

\subsection{The responsibility of the state in general}

In this respect the focus will be on five fundamental aspects.

\subsubsection{A state executes authority}

The state (government) is the most powerful institution in society, endued with authority by God himself (Rom. 13; Belgic Confession, art. 36; Heidelberg Catechism, 39:104). It is of paramount importance to note that God mandated (entrusted) governments with power that does not include a transfer of power, which would imply a deification of the government - an ever-present temptation for every government. Governments therefore have authority at their disposal (Rom. 13), but they should never become authoritarian (Rev. 13), which means they should never misuse their authority at the cost of the well-being of society.

Every state should always be on the alert for the ever-present danger of absolutising authority. Even a democracy may take on forms of authoritarianism. A democratic system as such does not (automatically) guarantee freedom and justice, because it can easily be manipulated and misused by authorities. Therefore it is important to emphasise the supremacy of the Constitution and the independence of the judicial system.

The authority of a government is demonstrated by the provision of a police (and military) service, an (independent) judicial system as well as a prison system. The well-functioning of all these services and systems is of utmost importance for combatting crime and violence, and the creation of a free and peaceful society.

\subsubsection{A state maintains law and order}

A large degree of consensus exists among Christians that God appoints authorities, "willing that the world should be governed by certain laws and policies, to the end that the dissoluteness of men might be restrained, and all things carried on among them with good order and decency" (Belgic Confession, art. 36).

Christians therefore obey authorities "in all things which are not repugnant to the Word of God" (Belgic Confession, art. 36), and pray for them "that we may live peaceful and quiet lives in all godliness and holiness" (1 Tim. 2:2; cf. Tit. 3:1; 1 Pet. 2:13-14). 
"Law and order", although wrongly absolutised during the years of apartheid, and at the expense of justice and fairness, are indispensable elements of a free and responsible society. Whereas order without justice ends up in dictatorship, justice without order amounts to anarchy.

\subsubsection{A state promotes justice and fairness}

As already stated, what was mostly lacking during the former political dispensation, was justice and fairness in almost all spheres of life. A government that is concerned with the political, economical and cultural well-being of all citizens, especially the poor and the marginalised, will spare no effort to promote justice and fairness in society. This point of departure implies that unjust structures have to be changed to the benefit of the people, especially the poor. The government has to continuously reassess the "philosophy of economy", whether a shift from (raw) capitalism to social democracy is necessary to improve the quality of life of all people. Great emphasis should be laid not only on political independence, but also on economical development and especially the creation of new jobs. In the light of these urgent issues the wisdom of the 30 billion rand weapon transaction must be questioned.

Although it would be simplistic to lay all the blame on apartheid for the pandemic proportions that crime and violence have acquired today, the aftermath effect of apartheid should not be forgotten. The frustration and humiliation - even hatred - evoked among the black population should not be underestimated. The perception cannot be suppressed that, as far as some of the farm attacks are concerned (I refer to the brutal way in which they are executed, sometimes without robbery), one is inclined to think that these murders are (at least partially) politically motivated. On the other hand, it would be very naive and one-sided to blame the apartheid era for all the excesses of crime and violence.

\subsubsection{A state secures freedom}

It is part and parcel of the responsibility of every government in the world to create and maintain a free environment for all its citizens, the more so if freedom is inscribed in the constitution of that country, as is the case in South Africa.

Our Constitution contains a Bill of Rights (Ch. 2), that functions like "a cornerstone of democracy in South Africa, and which enshrines the rights of all people in our country and affirms the democratic 
values of human dignity, equality and freedom" (2.7.1). This Bill declares that "the state must respect, protect, promote and fulfil the rights in the Bill of Rights" (2.7.2).

The Bill of Rights also clearly states that "everyone has inherent dignity and the right to have their dignity respected and protected" (2.10) and that "[e]veryone has the right to life" (2.11).

Special attention is paid to the concept of freedom (2.12 ff.), such as: freedom and security of person; freedom of religion, belief and opinion; freedom of expression; freedom of association; freedom of movement and residence; freedom of trade, occupation and profession.

In the context of our discussion it is important to refer to the right to life and to possess property, rights which should be respected, protected and promoted by the state.

In short: a responsible state should secure the freedom of its citizens as far as humanly possible. An excellent constitution on paper is not enough, the rights enshrined in a constitution should be vigorously protected, maintained and promoted by the state.

\subsubsection{A state enhances social moral regeneration}

Although the establishment, maintenance and improvement of public morality are not in the first instance the duty of the state, the state has indeed a responsibility in this regard and therefore should initiate, encourage and enhance public morality and moral orientation. State authorities should set the example themselves in public life and act as role models to be imitated by citizens.

The government must be commended for the establishment of the National Religious Forum as well as the Moral Regeneration Programme and be encouraged to extend these programmes. ${ }^{6}$

6 Whether it was expedient to appoint Mr. Jacob Zuma, who was implicated in the so-called weapon purchase scandal, to launch this programme is an open question and even a matter of concern. As we all know (now) Mr. Zuma was later dismissed from office by the State President, Mr. Thabo Mbeki. 


\subsection{The specific responsibility of the state as far as crime and violence are concerned}

In this regard we have to deal with two issues. The first one relates to the incidence of crime and violence, and the second to the way in which the government handles these matters.

\subsubsection{Incidence of crime}

As far as the incidence of crime and violence is concerned, one could reflect on perceptions, experiences and statistics.

\section{- Perceptions}

Perceptions are created by what we read in newspapers, hear on the radio, see on television and perceive in squatter camps, townships, towns, cities, on the roads and farms, namely a never ending flow of crime and violence. Private homes, even whole suburbs, motor vehicles, trucks and trains are increasingly and in more diverse and sophisticated ways secured and safeguarded. A foreigner who travels through South Africa may easily experience the country as a besieged environment.

\section{- Experiences of crime}

Another reality is how people experience crime and violence, that is to say, how many people have experienced various acts of crime and violence in their daily lives. Nowadays it rarely happens that one does not know someone who has not had some kind of experience with crime and violence. This is a very serious situation because of the detrimental and traumatic effect it has on people's lives (see Steyn \& Strydom, 2004:337-358). Statistics about the decrease of violence are meaningless as long as the day to day experiences of people contradict those statistics.

\section{- Statistics}

This situation now raises the question of statistics as well as the reliability of those statistics. From many sources I have compiled a general picture, which, even if some data may not be that accurate, is alarming and sensational enough (see Nel, 2002:8-20; De Beer, 2004:99-103)7:

7 See also information on crime statistics in Beeld, 04-03-2004:2; 21-09-2004:1; 22-09-2004:4; 06-08-2005:11. 
- South Africa is seen by many as one of the most violent countries in the world. According to Interpol South Africa was recently placed third out of 96 countries as far as murder is concerned, second as far as sexual abuse and first as far as rape is concerned.

- In South Africa someone is murdered every half-hour - more that 20000 per year.

- Since 1991 murders on farmers have increased by $96 \%$ and more than 2000 farmers have been killed since then - a situation that also has had a detrimental effect on thousands of farm workers who have to leave the farms for squatter camps.

- Every year at least 50000 women are raped in the country.

- 52 motor cars are hi-jacked each day, 32 in Gauteng alone.

- Every year 120000 motor vehicles are stolen in the country.

- Three out of ten deaths in South Africa are related to the (mis-) use of fire arms.

- In many townships gangsterism is the order of the day.

\subsubsection{Is enough done to manage the proportions of crime?}

The above-mentioned statistics raises the next question: Is the government doing enough to manage the epidemic (pandemic?) proportions of crime and violence in the country?

This issue entails at least three (many-faceted) questions:

- Can the police force cope with their task or do we experience an inefficient and even disillusioned force, undermined by internal corruption? Why are so many cases of murder unsolved? Why are there no efficient programme to rid the country of all illegal weapons (sporadic and strategic road blocks; check points at all main toll-gates)?

- Can the judicial system fulfil its task properly or do we experience too many backlogs, long delays, reports about incompetent prosecutors and even accusations of racism?

- How should we rate the success of the prison system if prisons are overcrowded (187 640 instead of 114787 prisoners - 
$161 \%)^{8}$, if many escapes take place and if internal corruption is reported regularly? How effective are the rehabilitation programmes?

\subsubsection{Society is almost on the brink of emergency}

We conclude with the following observation: Without minimising the gross violation of human rights and the serious nature of "institutional violence" during the former political dispensation of apartheid, we have to conclude - in the light of the available statistics - that the level of "criminal violence" in the new dispensation has reached such crisis proportions that society is almost on the brink of a state of emergency. Although there is appreciation for what the government has done - and is doing - to combat crime and violence, our general inference is that not enough is done and that many young South Africans leave the country, blaming the high crime rate for being one of the main reasons for their emigration.

\section{The calling of the church}

Four aspects should be considered in this regard.

\subsection{The church is an exemplary community}

There are many organisations and associations in society of which the church has a very unique and extraordinary identity. The church can be defined as the people of God, the body of Christ and the temple of the Spirit of God, in short, a sign of the kingdom of God, a signal of the new world of God as God would like the world to be. The church is (and should be) a community where love and hope, liberation and reconciliation are received, shared and proclaimed in an exceptional way.

As such, just by (truly) being a church, the existence of the church implies social criticism in society, where fear and hatred, disunity and despair often prevail (Koopman \& Vosloo, 2002:94-95). The cardinal and primary calling of the church in a society that is undermined by crime and violence is therefore to be church of Jesus Christ in the fullest sense of the word, to set an example to the outside world of how people should live together in peace and harmony. 
This peace and harmony is practised and strengthened by Sunday worship services where the gospel of the kingdom of God is preached and experienced by inter alia the sacraments of baptism and Holy Communion.

At this point it is necessary to elaborate on the importance of Holy Communion. Our Constitution refers to "equality", but I do not know of any greater equaliser in society than Holy Communion, the meal of reconciliation. When Christians partake of Holy Communion they are all equal in the eyes of God: rich and poor, employed and unemployed, employer and employee, black and white, streetworker and state president. I am not aware of any other organisation in society where reconciliation is celebrated in a more intimate and united way than what we experience in the church of Christ. The implication of this is that the disunity among churches, also between church families that are closely related to one another, functions as a stumbling block as far as the witness of the church in society is concerned.

However, if the church functions in an authentic way, it can transfer a message of hope, create room for moral orientation, shape a moral tradition and create an agent of moral action in the midst of a violent society (see Kretzschmar \& Hulley, 1998:33 who refer to Bruce Birch).

Society can also learn from the church how authority should be exercised - in an attitude of servitude - and even how to elect authorities (the origin of "democracy" can be traced back to the Reformed tradition of electing deacons, elders and ministers).

I have argued that the church is only "a sign of the kingdom", not the fulfilment of the kingdom. This point of departure implies that the church should always remind the state of the imperfection and incompleteness of human life and that in the end the new creation will be a gift of God, even if we should strive after and work for it as hard as we can.

A last remark in this regard. The church is a community in which prayer plays a very important role (1 Tim. 2:1-2). Prayers can move mountains (Matt. 17:20), cause rain (James 5:16-18), and change the hearts of (potential) criminals. A true church should never stop to pray for politicians, police, prisoners, warders, judges and criminals. "The prayer of a rigtheous man is powerful and effective." 


\subsection{The church has a unique message}

Not only is the church a unique community in society; it also has a unique message to society, that is the message of the kingdom of God. Reference to the kingdom of God implies that the message of the church is also relevant for society, but we must take into consideration that when the church refers to concepts like liberation and reconciliation etcetera, the meaning of these concepts have more depth and height, other connotations and nuances of meaning than those used for and associated with the meaning of liberation and reconciliation in a secular way and in a secular society. ${ }^{9}$ For example, we have to distinguish between political liberation and spiritual salvation/liberation, but we should not separate the two, because Christ's interest is directed to a person in his/her totality, his/her spiritual as well as material well-being (i.e. a person's "sin" as well as "bread").

The following aspects are important in this context (cf. Rom. 14:17):

\section{- The message of liberation}

The church proclaims the message of liberation, first from sin (Matt. $1: 21)$, but with clear consequences for all aspects of social life (Jonker, 1996:243-262; see also Van Wyk, 2001:397-427). Whenever $\sin$ is forgiven and the relation to God restored in Christ, slavery - and all forms of human oppression - are undermined and reshaped to take on new forms (Philemon).

\section{- The message of reconciliation}

The church proclaims the message of reconciliation and peace with God (2 Cor. 5:11-21), an aspect that should have a humane effect on a society in which Christians live and work together in many different relations (in SA almost $80 \%$ of the population are Christians; see Jonker, 1977:194-203; Heyns, 1986:110-115; Van der Watt et al., 2005; also Hay, 1998). It is (and should be) impossible for Christians to live in peace and love in the church and simultaneously instigate disharmony and retaliation in society. We are of course not speaking about "cheap reconciliation" but of "costly reconciliation" by which restitution is made for the wrongs of the

9 No matter how valuable the contribution of the Truth and Reconciliation Commission may have been to create an environment of acceptance in the country, it is primarily the (never ending) task of the church of Christ to preach and exemplify reconciliation in society. 
past, as far as possible and as meaningful as allowed in a world ruined by $\sin$.

\section{- The message of justification}

The church proclaims the message of justification, in which man's relation to God is restored through the work of Christ (Romans) - an act with clear social implications (Heyns, 1982:274-289; 1986:105109). It is (and should be) impossible for Christians to be restored in their relation to God on the one hand, but on the other hand, to continue a life of injustice in society.

It is also the urgent task of the church (and theology) to examine (and evaluate in the light of Scripture and the principles of the kingdom of God) the ideological presuppositions that underly every economical system - whether it is just or unjust (see Leatt et al., 1986). ${ }^{10}$

\section{- The message or love}

The church proclaims the message of love, first to God and then to the neighbour, including the enemy. To love one's enemy, to the same extent as God loves us (Rom. 5:10), is the hallmark of a true Christian (Matt. 5:48).

Fundamentally it is the love for human beings that motivates the church to reach out, assist and uplift the poor, the have-nots, the unemployed and the downtrodden in society. It is love for human beings that inspires the church to (pastorally) assist those in prisons as well as those who are traumatised by crime and violence.

\section{- Preciousness of life}

The church emphasises the preciousness of human beings and human life, because man is created in the image of God (see J.M.Vorster, 2004:121-138; Nel, 2002:56-58). Nobody has the right to murder someone who is created in the image of God (Gen. 9:6; Ex. 20:13; see Heidelberg Catechism, 40:105-107).

10 See also the relevant article of Flip Buys in Rapport (15-05-2005:13 - "Het die kapitalisme dan nou misluk?") in which he criticises radical capitalism that only considers the market system as important and not the human beings who function in the system. 


\section{- Right of property}

The church teaches the right of property and that it is a crime to steal from someone else (Ex. 20:15; see Heidelberg Catechism, 42:110-111).

What could be the effect on society if white ministers in predominant "white" congregations, and black ministers in predominant "black" congregations, boldly preach the message of love, reconciliation, peace and justice? Will it not diminish black hate and white fear? Who can calculate the effect of a timely sermon on the conscience of a politician, minister or state president? To imitate Shakespeare: "The sermon's the thing to catch the conscience of the king!"

\subsection{What do we refer to when we speak of "the church"?11}

The meaning of the concept church has to be refined in order to distinguish between the different "configurations" of the concept church.

There is, to begin with, the individual church member, who functions inside and outside the church community as a follower of Christ. Whether he/she is a member of parliament, political party, economic company, cultural organisation, or any other society, nowhere is it allowed to ignore, despise or transgress moral (Christian) values and norms. On the contrary, these values and norms should be boldly proclaimed and put into practice in all spheres of life.

A clear example of this attitude to life and the practice of convictions could be found in the way Beyers Naudé witnessed against apartheid, and Archbishop Desmond Tutu criticised Mr. Thabo Mbeki during November 2004.12 The President sharply repudiated the Bishop for his criticism, a reaction that leads us to conclude that the outcome of the debate was not convincing and encouraging for future developments. Authorities too often do not want to be criticised and corrected. Politics is, however, far too important to be left to politicians alone!

In the second place we refer to the calling and prophetic witness displayed by the local church - an aspect never to be

11 See in this regard Van Wyk (1991:96-104); Smit (1996:201-202); Koopman and Vosloo (2002:130-140); Coetzee, (2004:333-34).

12 Tutu criticised Mbeki for his handling of the issues of Aids, Zimbabwe and the black empowerment scheme. 
underestimated. Although the radius of influence may be limited, it may have a great positive effect on local events.

A third possibility is that of a synodical witness in society - a statement (wrongly) seen by most people as "the voice of the church". It is true that church assemblies should deal only with "ecclesiastical matters in an ecclesiastical manner" (Church Order, GKSA art. 30). However, when we define the church as a sign of the kingdom of God, "ecclesiastical matters" should refer to all matters that concern the kingdom of God, implying all matters that concern God, man and his world (see Vorster, 1999:54-57). All these matters should, however, be dealt with in an ecclesiastical - and not political - way. A situation may thus arise where the church "must bear testimony to the government in cases where the need to do so occurs" (Church Order, GKSA, art 28).

A fourth option is ecumenical co-operation, because, as we have experienced during the days of apartheid that a contradictory witness from the churches is a misguided witness, a united witness from all the church "denominations" in a country renders much more credibility to that witness. In such instances the government is offered no opportunity to play off the witness of one church against the other (N. Vorster, 2004:540).

A fifth option to view the church is - what Kuyper called - the view of the church as organism - a notion that has also been heavily criticised (see Van Leeuwen, 1946:106-121). What is at stake in this respect is a situation in which Christians start a cultural organisation through which they influence and also criticise - when neseccary the politics of the day. A clear example of this approach in South Africa is to be found in The Reformational Movement of Southern Africa (Remsa - earlier called the Afrikaanse Calvinistiese Beweging), with its mouthpiece, the journal Woord en Daad (Word and Action).

In the sixth place I would recommend that in cases of shared values, and without sacrificing any Christian values or norms, churches should co-operate with other religions to further peace and stability and to fight crime and violence.

\subsection{How should churches influence the government?}

A last question remains: How should churches influence the government, also with regard to crime and violence? (see J.M. Vorster, 2004:284-287). 
In first instance I think of public encounters - like Mr. Mbeki permitted (and practised) in the past. The initiative could begin either by politicians or churches, and it could involve matters of joint concern and public interest, in this case crime and violence.

A second option is to create a system within which the church develops a permanent monitoring and lobbying structure with the view of influencing national, provincial and local authorities (Afrikaans: wandelgang-politiek) - which, to a certain extent is the case today (see Villa-Vicencio, 1995:61). In this way churches could operate in a pro-active way and not - as in the past - operate reactively and when it is too late (see N. Vorster, 2004:538).

A third possibility is public and prophetic witness by (if possible all) churches in a country whenever a state of emergency develops. Two examples of this nature are the Barmen Declaration of 1934 in Germany and the Belhar Confession of 1986 in South Africa.

A fourth prospect is when Christians, in cases of gross violation of religious and/or human rights use the method of peaceful nonviolent protest and demonstration to influence (and change) the opinion of the government. The first instance of such protest against violence occurred in Pretoria on 24 September 2003 after the murder of the one-year-old Kayla Rawstorne, her mother and grandmother.13 A second demonstration was held in Johannesburg on 30 November 2004 by Lynn Vince-Jillings (from AL-LIVE) after the murder of her twenty-year-old son. ${ }^{14}$

\section{Conclusion}

\subsection{The responsibility of the government}

- The phenomenon of crime should be viewed and approached by the South African government within the wider social context in which we experience many other social problems like poverty, unemployment, Aids, etcetera.

- The government should supply a well-equipped, well-organised, well-paid and efficient police force. The experience of many

13 I participated in this protest with two of my grandsons. On the one side of the poster the following slogan appeared: "Beskerm ons kinders", on the other "Christus is ons vrede".

14 The government refused to be involved. 
people in squatter camps, townships, towns and cities is that the police are losing the battle against crime.

- The government should provide a well-organised, efficient and independent judicial system.

- The government has the immense task of finding immediate solutions for the far too overcrowded prisons, a situation which is, also from a humanitarian point of view, totally unacceptable.

- The government should strive to deal with the causes of crime (inter alia poverty and unemployment) in order to eliminate them as far as possible.

- The government must develop a well-considered strategic plan to deal with and to end crime and violence in the country.

- The government has the responsibility and authority to create a free, just, orderly and peaceful society in South Africa.

\subsection{The calling of the church ${ }^{15}$}

- The church should set a true example of what it means to live in a spirit of freedom, reconciliation, peace, justice and love.

- The church (ministers and pastors) should continue to preach the gospel of the kingdom - which contains a message of righteousness, peace and joy in the Holy Spirit (Rom. 14:17) - to all believers and appeal to them to live in all circumstances like true followers of Jesus Christ.

- The church should create a new sense of what it means to be a "community" in the true sense of the word, in a society caught up in many sharp divisions of colour, race and class.

- The church, in all its different "configurations", and in many different ways, must co-operate with the government to combat crime and violence, and where necessary to deliver a prophetic witness, and even openly protest, should the government fail to secure peace, security and freedom.

15 In De Gruchy's well known book, The church struggle in South Africa (third edition, 2004), "crime" as one of the new "struggles" with which the church has to deal in future is not specifically referred to in the concluding chapter of the book. 
- The church should continue to pray for all those in positions of authority, for the police and for every human being in society, including those who are potential criminals - to change their minds and hearts. "Change of heart is the heart of change."

- The church has to make it very clear that a society without public morality is a society on the brink of anarchy. The church has to do its very best to (re-)build the moral orientation of society (see Bam, 1995:51).

- The church must co-operate with the state and society to establish and promote an ethos of respect for human beings, human life and the property of other people.

- The church should assist the government and educational institutions to develop a Code of Conduct ${ }^{16}$ that includes not only human rights but also human responsibilities, aspects that should be vigorously promoted in society in order to form part and parcel of the moral orientation of each citizen.

\section{A last word}

I conclude by stating that we have arrived at a situation in South Africa where public outcry and protest against crime and violence, accompanied by a strategic plan, is inevitable. We need a wellorganised nation-wide public protest against this pandemic.

South Africa is in desperate need of a new moral orientation and a culture of respect for human lives and other's possessions.

\section{List of references}

BAM, B.H. 1995. The church in South Africa. (In Pityana, B.N. \& Villa-Vicencio, C., eds. Being the church in South Africa today. Johannesburg: SACC. p. 43-53.)

BERKOUWER, G.C. 1970. De kerk I: eenheid en katholiciteit. Kampen: Kok. BERKOUWER, G.C. 1972. De kerk II: apostoliciteit en heiligheid. Kampen: Kok.

16 Such a code of conduct may contain the following requirements: respect for the religion of others; respect for human life and human beings; respect for the possessions of others; respect for marriage life; respect for truth; respect for the language and culture of others; respect for (good) authority; respect for the environment and creation. The present curriculum, which deals with human rights and responsibilities and which is presented in our schools today, is to be welcomed and has to be extended. 
COETZEE, C.F.C. 2004. Violence in post-apartheid South Africa and the role of the church and theology. In die Skriflig, 38(2):333-348.

CONSTITUTION OF THE REPUBLIC OF SOUTH AFRICA see SOUTH AFRICA. 1996.

DE BEER, E.J. 2004. Die vergoeding vir arbeid in Suid-Afrika: 'n teologiesetiese studie. Potchefstroom: PU vir CHO. (Ph.D.-proefskrif.)

DE GRUCHY, J.W. \& DE GRUCHY, S. 2004. The church struggle in South Africa. London: SCM.

DE VILLIERS, E. 1996. The challenge to the Afrikaans churches. (In Botman, H.R \& Petersen, R.M., eds. To remember and to heal: theological and psychological reflections on truth and reconciliation. Cape Town: Human \& Rousseau. p. 140-153.)

GILIOMEE, H. 2003. The Afrikaners: biography of a people. Cape Town: Tafelberg.

HAY, M. 1998. Reconciliation in South Africa. Pietermaritzburg: Cluster.

HEYNS, J. 1982. Teologiese etiek I. Pretoria: N.G. Kerkboekhandel.

HEYNS, J.A. 1986. Teologiese etiek 2/1. Pretoria: N.G. Kerkboekhandel.

JONKER, W.D. 1977. Christus, die middelaar. Pretoria: N.G. Kerkboekhandel.

JONKER, W.D. 1996. The Gospel and political freedom: aspects of a South African debate. (In Van Egmond, A. \& Van Keulen, D., eds. Freedom: studies in reformed theology I. Baarn: Callenbach. p. 243-262.)

KOOPMAN, N. \& VOSLOO, R. 2002. Die ligtheid van die lig: morele oriëntasie in 'n postmoderne tyd. Wellington: Lux Verbi.BM.

KRETZSCHMAR, L. \& HULLEY, L. 1998. About life and morality: Christian ethics in South Africa today. Pretoria: Van Schaik.

KÜNG, H. 1967. De kerk. Antwerpen: Paul Brand.

LEATT, J., KNEIFEL, T. \& NÜRNBERGER, K., eds. 1986. Contending ideologies in South Africa. Grand Rapids: Eerdmans.

MOLTMANN, J. 1975. Kirche in der Kraft des Geistes. München: Kaiser.

NEL, L.A.S. 2002. Kerk en geweldsmisdaad in Suid-Afrika - 'n teologies-etiese studie. Potchefstroom: PU vir $\mathrm{CHO}$ (Th.M.-verhandeling.)

PRETORIUS, F. 1998. Die Anglo-Boereoorlog 1899-1902. Kaapstad: Struik.

SMIT, D. 1996. Oor die unieke rol van die kerk. Tydskrif vir Geesteswetenskappe, 36(3):190-204.

SOUTH AFRICA. 1996. Constitution of the Republic of South Africa. Pretoria: State Printers.

STEYN, M.M. \& STRYDOM, H. 2004. Misdaad en die impak daarvan op die mens - 'n Christelike perspektief. Koers, 29(2):337-358.

VAN DER WATT, J., HUMAN, D. \& STEYN, G. 2005. Friendship and love where there were none: Biblical perspectives on reconciliation. Pretoria: IMER.

VAN LEEUWEN, P.A. 1946. Het kerkbegrip in de theologie van Abraham Kuyper. Wever: Franeker.

VAN WYK, J.H. 1991. Moraliteit en verantwoordelikheid: opstelle oor politieke etiek. Potchefstroom: $\mathrm{PU}$ vir $\mathrm{CHO}$.

VAN WYK, J.H. 2001. Etiek en eksistensie in koninkryksperspektief. Potchefstroom: Potchefstroomse Teologiese Publikasies.

VAN'T SPIJKER, W., BALKE, W., EXALTO, K. \& VAN DRIEL, L., reds. 1990. De Kerk: wezen, weg en werk van de kerk naar reformatorisch opvatting. Kampen: De Groot Goudriaan. 
VILLA-VICENCIO, C. 1995. Freedom is forever unfinished: the incomplete theological agenda. (In Pityana, B.N. \& Villa-Vicencio, C., ed. Being the church in South Africa today. Johannesburg: SACC. p. 57-72.)

VORSTER, J.M. 1999. An introduction to Reformed church polity. Potchefstroom: Potchefstroomse Teologiese Publikasies.

VORSTER, J.M. 2004. Ethical perspectives on human rights. Potchefstroom: Potchefstroomse Teologiese Publikasies.

VORSTER, N. 2004. Die kerk en openbare beleidsvorming - 'n praktiese voorstel vir gereformeerde getuienis. In die Skriflig, 38(3):517-545.

\section{Key concepts:}

church: calling regarding crime and violence

crime and violence

state: responsibility towards crime and violence

state and church: relation between

\section{Kernbegrippe:}

kerk: roeping ten opsigte van misdaad en geweld

misdaad en geweld

staat: verantwoordelikheid ten opsigte van misdaad en geweld staat en kerk: verhouding tussen 
